\title{
Student Engagement in a Compulsory Introductory Physiology Course
}

\begin{abstract}
S.J. Brown ${ }^{1}$, S.White ${ }^{2}$, A. Bowmar ${ }^{3}$, and N. Power ${ }^{4}$
Abstract: Appropriate instruments are required to determine student engagement on an undergraduate course, and in this study we evaluated a 23 item Student Course Engagement Questionnaire (SCEQ) administered to undergraduate students studying a Bachelor of Sport and Recreation degree. These students were in the first semester of a 3 year degree, and were enrolled in a compulsory introductory Human anatomy and physiology course, as part of their degree. Responses $(n=115)$ were analysed using exploratory factor analysis, and this indicated that 4 latent factors explained $>49 \%$ of the total variance. These factors were described as 'study habits' (7 items), 'performance' (6 items), participation (4 items), and emotional (4 items). Two items did not align with any latent factors. Each scale had good internal consistency, with all Cronbach's alpha values $>0.7$. The factors identified in this study are consistent with those identified in a previous SCEQ evaluation, and we suggest that this instrument is appropriate to quantify course engagement in Sport and Recreation degree students. Moreover, we suggest that the scales identified within the SCEQ may be used to quantify aspects of engagement in undergraduate students studying a course in introductory Human anatomy and physiology.
\end{abstract}

Keywords: engagement, undergraduate, anatomy and physiology, sport studies.

\section{Introduction}

Student engagement with a University undergraduate course may improve a student's confidence with the content of the course, and it may improve their academic performance on the course. A student may learn by being more engaged, and this may have positive effects on persistence, student satisfaction, and academic success. Collectively, these may contribute positively to the overall student experience on an undergraduate course, benefiting not only students, but also institutions, as they can potentially demonstrate that by engaging a student on a course, they are adding to the value of the education they provide (Kuh et al. 2008). Also, increased student engagement may encourage a student to complete their chosen programme of study and graduate from University. However, levels of student engagement with an undergraduate course at University are rarely measured and this may be partly due to a lack of appropriate instruments to quantify course engagement. Therefore, in this study, we evaluate a Student Course Engagement Questionnaire (SCEQ) - originally proposed by Handelsman et al (2005), to quantify course engagement in undergraduate students studying at University.

The initial evaluation and validation of the SCEQ instrument was performed on data from undergraduates in the disciplines of psychology, political science, and mathematics. This evaluation used an exploratory factor analysis (EFA) approach and identified 4 latent factors within the SCEQ - these were termed 'Skills Engagement', 'Emotional Engagement', 'Participation/interaction Engagement', and 'Performance Engagement'. This internal data structure is congruent with behavioural and affective constructs of engagement (Herrmann

\footnotetext{
${ }^{1}$ Auckland University of Technology, stbrown@aut.ac.nz.

2 Auckland University of Technology, suwhite@aut.ac.nz.

${ }^{3}$ Auckland University of Technology, abowmar@aut.ac.nz.

${ }^{4}$ Auckland University of Technology, npower@aut.ac.nz.
} 
Brown, White, Bowmar, and Power

2013), whereby the behavioural component describes a student's motives to study (performance engagement) and their strategies to succeed (skills engagement), and the affective component describes both emotional engagement and their willingness to interact with others (participation/interaction engagement). Students who become engaged participants in the

classroom may be motivated to engage more meaningfully in both their individual study, and with their chosen course of study (Miller and Metz 2014). This includes a student's willingness to engage in class discussion by putting forward their opinions and offering comments (Herrmann 2013). Student engagement can also be increased through the use of collaborative active learning, using a technique that has a group of students solving the same academic problems together (Zhao and Kuh 2004). This collaboration between students may increase individual academic performance by fostering both behavioural engagement (improving study skills) and emotional engagement through commitment and connecting with colleagues. Although the majority of students may prefer an engaging, active learning format, some students still maintain a preference for the traditional didactic lecture (Huang and Carroll 1997; Miller at al. 2013). Traditional lectures allow the lecturer's personal overview of content, integrating information from multiple sources, and may clarify complex information.

Despite the availability of the SECQ instrument, there is a paucity of data on course engagement, and currently there are no data available on the engagement of sport and recreation students with an introductory course in Human anatomy and physiology. We have chosen to study engagement in this group of students because a course in Human anatomy and physiology contains essential core knowledge for many health related degrees, including exercise science, kinesiology, and sport and recreation degrees. This core knowledge has fundamental principles to aid the understanding of more in-depth physiology (Modell 2000; Michael et al. 2008; Michael and McFarland 2011), and principles which underpin a further understanding of exercise physiology (Henige 2012). However, sport science students may struggle to pass a course in physiology despite finding it to be relevant to their studies (Higgins-Opitz and Tufts 2014), yet there have been few reports on factors that can predict success in physiology in health science students, particularly those enrolled in sport science. It has been suggested that probing why many sport science students experience difficulty passing an introductory course in physiology may be both helpful and worthwhile (Higgins-Opitz and Tufts 2014).

Therefore, in the current study, we aimed to evaluate a course engagement questionnaire when used with sport and recreation students studying an introductory course in Human anatomy and physiology.

\section{Methods}

\section{Course and setting}

This study was approved by the University's Human Ethics Committee and carried out at a large publicly funded higher education institution. A compulsory introductory course in Human anatomy and physiology was taught to all Bachelor of Sport and Recreation students in their first semester of their first year of study. Passing this course was a requirement for continued progression beyond the first semester, or transferring into other health science programmes (for example, physiotherapy). The Sport and Recreation programme typically attracted students with a diverse range of pre-university educational experiences, including both school leavers and those re-entering formal education following a period of either work or unemployment. The gender balance was approximately 1:1 (male:female). Demographics of the students were not specifically collected for this study, as access to both student identity and confidential personal details were restricted by the Ethics Committee.

Journal of the Scholarship of Teaching and Learning, Vol. 17, No. 1, February 2017. 
Brown, White, Bowmar, and Power

The course was delivered as a weekly three hour lecture (recorded at the time of initial delivery and made available to all students for the remainder of the course), and a weekly 2 hour tutorial, over a continuous 13 week period. All lecture slides could be pre-purchased by students, and additional work sheets were used to support learning outcomes in the tutorial sessions. Two, one

hour laboratory sessions were also part of the course, these being a bone and joint dissection (bovine), and a heart and lung dissection (lamb). Students were strongly encouraged to purchase

\section{STUDENT COURSE ENGAGEMENT}

\section{QUESTIONNAIRE (SCEQ)}

\section{INSTRUCTIONS}

- By completing this questionnaire you are consenting to take part in this study.

- This test contains a number of statements about student's engagement towards learning. You will be asked what you think about these statements, and how they apply to you. There are no 'right' or 'wrong' answers.

- If the statement is "more like you" choose a response of 4, if it is "much more like you" choose a response of 5.

- If the statement is "less like me" choose a response of 2, if it is "much less like me" choose a response of 1.

- If there is no preference, i.e. neither "like me" or "not like me", then choose a response of 3.

- For questions $1-23$, draw a circle around your response:

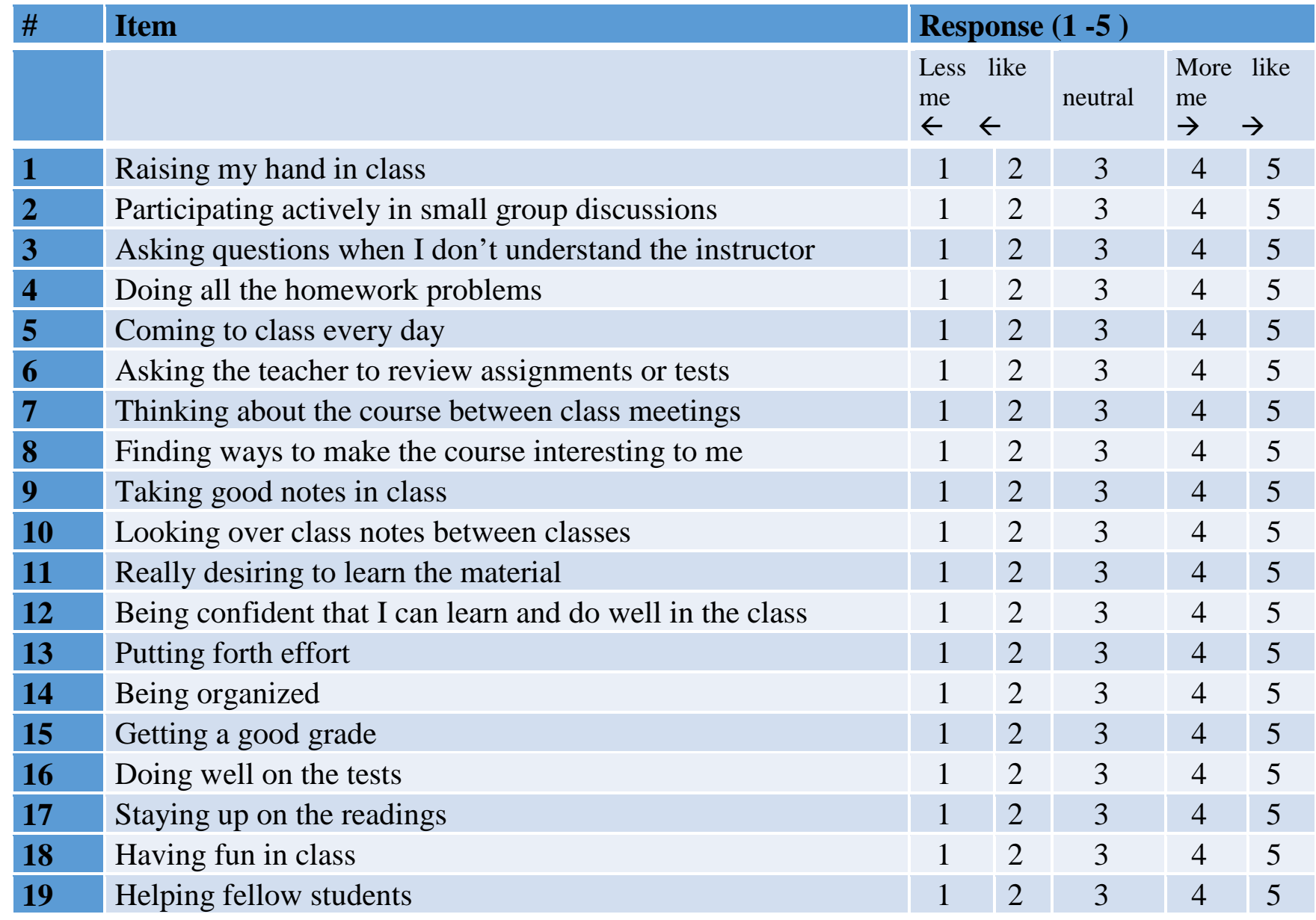

Journal of the Scholarship of Teaching and Learning, Vol. 17, No. 1, February 2017. 
Brown, White, Bowmar, and Power

\begin{tabular}{|l|l|l|l|l|l|l|}
\hline $\mathbf{2 0}$ & Making sure to study on a regular basis & 1 & 2 & 3 & 4 & 5 \\
\hline $\mathbf{2 1}$ & Finding ways to make the course material relevant to my life & 1 & 2 & 3 & 4 & 5 \\
\hline $\mathbf{2 2}$ & Applying course material to my life & 1 & 2 & 3 & 4 & 5 \\
\hline $\mathbf{2 3}$ & Listening carefully in class & 1 & 2 & 3 & 4 & 5 \\
\hline
\end{tabular}

Figure 1. The Student Course Engagement Questionnaire (SCEQ).

an introductory anatomy and physiology textbook, and although not compulsory, attendance at both lectures and tutorials was strongly encouraged.

\section{Data collection and analysis}

The Student Course Engagement Questionnaire (SCEQ - see figure 1) was administered to students by administrative staff not responsible for teaching or assessing the students. Data were collected in week 4 of the course as this was before any major assessment (a mid-semester test was carried out in week 6) but captured all enrolled students (the late enrolment period extended to the end of week 2 of the semester). The questionnaire has 23 equally weighted items each assessed using a 5-point Likert scale. All students were given appropriate instruction on completing the questionnaire and were given a participant information sheet which described the background and purpose of the research. By completing the SCEQ, the participant had consented to take part in the study. The $1-5$ Likert scale indicated responses to statements where 1 indicated that the statement was "much less like me", whereas 5 indicated that the statement was "much more like me". The middle point on the scale (3) indicated no preference, such that the statement was neither "more like me" nor "less like me".

All data collected were analysed using appropriate software (IBM SPSS version 22). An exploratory factor analysis was performed on questionnaire responses using the principle axis factoring method with varimax rotation. An initial 4 factor solution explained more than $49 \%$ of the total variance, and internal validity of these factors was assessed using Cronbach's alpha $(\alpha)$ coefficient.

\section{Results}

Completed SCEQ's were returned from 115 students - a response rate of $>90 \%$. An initial exploratory factor analysis indicated that four latent factors explained more than $49 \%$ of the total variance, and the Kaiser-Meyer-Olkin value was 0.741 - this indicates that the data were suitable for this type of analysis. Eigenvalues and the \% of total variance explained by each extracted factor are shown in table 1.

Table 1. Factors identified by the exploratory factor analysis, their associated Eigenvalue, and the variance explained by each factor.

\begin{tabular}{llll}
\hline Factor & Eigenvalue & \% of Variance & Cumulative \% \\
\hline 1 & 5.651 & 15.721 & 15.721 \\
2 & 2.330 & 13.419 & 29.140 \\
3 & 1.755 & 10.305 & 39.445 \\
4 & 1.543 & 9.594 & 49.039 \\
\hline
\end{tabular}

Journal of the Scholarship of Teaching and Learning, Vol. 17, No. 1, February 2017. 
Identified in Table 2 are the item loadings for each factor (loadings $\leq 0.42$ are omitted), and the internal consistency $(\alpha)$ of each factor. Also shown in table 2 is the descriptive term for each item used by Handelsman et al (2005) in the initial evaluation of the SCEQ, and our suggested

description of the factor.

Table 2. Factor loadings, reliability coefficients, and descriptors.

\begin{tabular}{|c|c|c|c|c|c|c|}
\hline \multirow[b]{3}{*}{ Item } & \multicolumn{4}{|l|}{ Factor } & \multirow{3}{*}{$\begin{array}{l}\text { Handelsman et } \\
\text { al. (2005) }\end{array}$} & \multirow{3}{*}{$\begin{array}{l}\text { Suggested } \\
\text { description }\end{array}$} \\
\hline & 1 & 2 & 3 & 4 & & \\
\hline & $\alpha=0.796$ & $\alpha=0.710$ & $\alpha=0.748$ & $\alpha=0.750$ & & \\
\hline Q7 & .814 & & & & Emotion & \\
\hline Q11 & 686 & & & & Emotion & \\
\hline Q13 & .659 & & & & Skills & \\
\hline Q10 & .526 & & & & Skills & Study habits \\
\hline Q20 & .475 & & & & Skills & \\
\hline Q6 & .468 & & & & Participation & \\
\hline Q23 & .423 & & & & Skills & \\
\hline Q16 & & .761 & & & Performance & \\
\hline Q15 & & .751 & & & Performance & \\
\hline Q12 & & .596 & & & Performance & Performance \\
\hline Q17 & & .585 & & & Skills & \\
\hline Q9 & & .470 & & & Skills & \\
\hline Q4 & & .448 & & & Skills & \\
\hline Q2 & & & .719 & & Participation & \\
\hline Q19 & & & .715 & & Participation & Particination \\
\hline Q18 & & & .669 & & Participation & Participation \\
\hline Q1 & & & .472 & & Participation & \\
\hline Q21 & & & & .760 & Emotion & \\
\hline Q22 & & & & .741 & Emotion & Emotional \\
\hline Q8 & & & & .570 & Emotion & \\
\hline Q5 & & & & .525 & Skills & \\
\hline
\end{tabular}

The latent factors identified in the exploratory factor analysis are also shown in figure 2. In this figure we also report the Cronbach's alpha values to indicate internal consistency of the items contributing to the factor. In this figure, we suggest that each of the four factors identified in the exploratory factor analysis contribute to overall course engagement, however, we do not suggest

Journal of the Scholarship of Teaching and Learning, Vol. 17, No. 1, February 2017. 
Brown, White, Bowmar, and Power

that each factor is making an equal contribution. Table 3 describes the 4 identified factors with suggested descriptors. These terms are consistent with those used in the initial SCEQ evaluation, although factor 1 has been described as 'Study habits' instead of 'skills' as this reflects the combination of skills, participation, and emotional items which contribute to factor 1 . The SCEQ items which load onto the factor are listed in full in table 3.

Table 3. SCEQ items which form each identified factor.

\begin{tabular}{|c|c|c|c|}
\hline \multicolumn{4}{|l|}{ Factor } \\
\hline 1 & 2 & 3 & 4 \\
\hline Study habits & Performance & Participation & Emotional \\
\hline $\begin{array}{l}\text { Thinking about the } \\
\text { course between } \\
\text { class meetings }\end{array}$ & $\begin{array}{l}\text { Doing well on the } \\
\text { tests }\end{array}$ & $\begin{array}{l}\text { Participating } \\
\text { actively in small } \\
\text { group discussions }\end{array}$ & $\begin{array}{l}\text { Finding ways to } \\
\text { make the course } \\
\text { material relevant to } \\
\text { my life }\end{array}$ \\
\hline $\begin{array}{l}\text { Really desiring to } \\
\text { learn the material }\end{array}$ & $\begin{array}{lll}\begin{array}{l}\text { Getting } \\
\text { grade }\end{array} & \text { a } \text { good } \\
\end{array}$ & $\begin{array}{ll}\text { Helping } & \text { fellow } \\
\text { students } & \\
\end{array}$ & $\begin{array}{l}\text { Applying course } \\
\text { material to my life }\end{array}$ \\
\hline Putting forth effort & $\begin{array}{l}\text { Being confident } \\
\text { that I can learn and } \\
\text { do well in the class }\end{array}$ & Having fun in class & $\begin{array}{l}\text { Finding ways to } \\
\text { make the course } \\
\text { interesting to me }\end{array}$ \\
\hline $\begin{array}{lr}\begin{array}{l}\text { Looking } \\
\text { notes }\end{array} & \text { between } \\
\text { classes } & \\
\end{array}$ & $\begin{array}{l}\text { Staying up on the } \\
\text { readings }\end{array}$ & $\begin{array}{l}\text { Raising my hand in } \\
\text { class }\end{array}$ & $\begin{array}{l}\text { Coming to class } \\
\text { every day }\end{array}$ \\
\hline $\begin{array}{l}\text { Making sure to } \\
\text { study on a regular } \\
\text { basis }\end{array}$ & $\begin{array}{l}\text { Taking good notes } \\
\text { in class }\end{array}$ & & \\
\hline $\begin{array}{l}\text { Asking the teacher } \\
\text { to review } \\
\text { assignments or tests }\end{array}$ & $\begin{array}{l}\text { Doing all the } \\
\text { homework } \\
\text { problems }\end{array}$ & & \\
\hline $\begin{array}{l}\text { Listening carefully } \\
\text { in class }\end{array}$ & & & \\
\hline
\end{tabular}

\section{Discussion}

This study reports an initial factor analysis and scale development of an instrument to measure student course engagement, when that instrument is used in a group of Bachelor of Sport and Recreation students studying an introductory course in Human anatomy and physiology. We suggest there is a need for an appropriate tool to measure course engagement as it could be used to quantify the impact of novel pedagogies aimed at improving a student's engagement.

Furthermore, we suggest there is a current paucity of data on course engagement in this context, and therefore any potential relations between student engagement and either student satisfaction or academic performance, remain only speculative.

During the initial SCEQ evaluation, Handelsman et al (2005) performed principal axis factoring with varimax rotation on a 27 student engagement inventory, and subsequently reduced the number of items in the inventory to 23 . These authors reported that a four factor structure was applicable to the 23 item inventory, and that these four latent factors accounted for $42.69 \%$ of the 
Brown, White, Bowmar, and Power

total variance. In the current study, our exploratory factor analysis (using the same principal axis factoring method with varimax rotation), also identified 4 latent factors which showed some consistency with those reported elsewhere (Handelsman et al., 2005). The reliability estimates in the current study for each factor (see figure 2) are also comparable with those reported by

Handelsman et al. (2005), as is the total variance explained by the four factors (49\%). However, the initial evaluation of the SCEQ was with students studying psychology, political science, and mathematics, whereas in the current study, the students were studying Human anatomy and physiology as part of a Bachelor's degree in Sport and Recreation - this is a unique approach using the SCEQ.

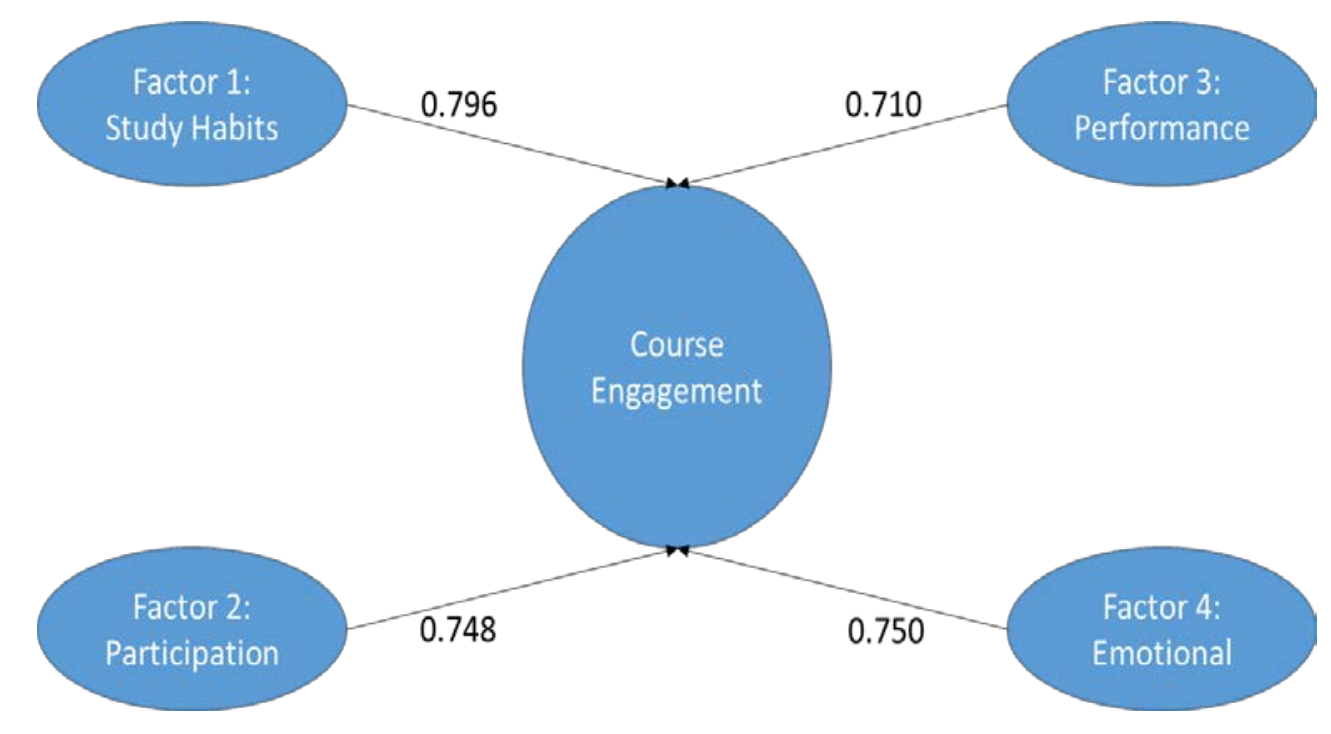

Figure 2. Suggested factor structure of student course engagement.

University programmes in sport science, sport and recreation, and exercise kinesiology, are commonplace - many require an understanding of the Human body and its physiology.

Introductory courses in anatomy and physiology may be based around core principles with their origins in biology (Michael et al., 2008; Michael et al., 2009), although there is no firm consensus about the content within an introductory course in physiology (Rathner et al., 2013). Students on named degree pathways which focus on topics such as exercise and sport, may fail to engage fully with a generalised Human anatomy and physiology course, unless the examples used to demonstrate core principles are explicit with regard to sport and exercise. Therefore, we suggest that the SCEQ instrument is a useful tool to measure course engagement in this context. Novel teaching pedagogies in both the health science and physiology curricula which either match teaching methods with different learning styles (Allers 2010; Eagleton and Muller, 2011), or incorporate an active learning approach (Vanags et al., 2012; Wilke 2003) have been proposed (Ernst and Colthorpe, 2007; Higgins-Opitz and Tufts, 2010; Henige 2012). These new pedagogies are intended to improve student academic performance, however, we suggest that the impact of these novel teaching strategies on student engagement is also of considerable interest. Moreover, we suggest that the SCEQ is a useful tool to quantify the impact of these pedagogies on student engagement with an introductory course in physiology. For example, active learning pedagogies may increase the engagement of some learners, particularly when it equates to practical experiences (Levett-Jones et al., 2015). However, teaching in large groups with only few students playing an active role in practical activities (while most students observe) may only 
Brown, White, Bowmar, and Power

engage the active student, and potentially disengage those merely observing. Alternatively, courses which include process-based learning, group work, and student response systems may improve student academic performance (Armbruster et al., 2009: Brown, 2010), but it remains speculation that this may be due to increased student engagement with the course. Pedagogies which require more independence and academic maturity on the part of the student may also

impact student engagement (Eberlein et al., 2008). For example, more independent and mature students can be more engaged with a course, and this may improve their academic performance, whereas other students who lack independence and maturity may disengage with a course in which alternative pedagogies are prevalent. We propose that our evaluation of the SCEQ with sport and recreation students may allow the quantification of engagement in courses where alternative teaching strategies are adopted.

Currently there is a paucity of papers on the early identification of health science students who are struggling with their studies (Higgins-Opitz and Tufts, 2014; Shaban and McLean, 2011) particularly in large, diverse, and multidisciplinary modules. For example, in a large Human anatomy and physiology course (with class numbers of $>200$ ) comprising four very different health science specialties (audiology, speech language pathology, dental therapy and oral health, and sport science), pass rates of the sport science students were considerably lower than those of students from the other three health science qualifications (Higgins-Opitz and Tufts, 2014). These authors further reported that most students recognized the relevance of physiology in their professional degree, and of those students who answered positively, the majority were sport science students. Of the $10 \%$ of students who did not perceive physiology to be relevant to their studies, the majority were again sport science students (Higgins-Opitz and Tufts, 2014). A student's tertiary entrance qualification may correlate with achievement in a human physiology course (Rathner et al., 2013) and therefore be an adequate predictor of success on the course, but there are no data to support a correlation between entrance qualifications and course engagement. Thus, we propose that the SCEQ, when used in a population of students studying sport and exercise, may identify students who are disengaged with their physiology course, and potentially identify students at risk of failing the course.

Although engagement with a course may be beneficial to the overall student experience at university, the correlation between engagement and academic performance may be weak. For example, a student may be disengaged with the course yet score highly on academic tests, and equally, a fully engaged student may perform poorly on academic tests. This correlation may be even weaker in large multidisciplinary cohorts studying courses in which the content may appear to be outside the core content of a named pathway. Therefore, the need to measure course engagement (for example, using the SCEQ) is as relevant in these types of courses as it is in smaller, specific courses.

In this study, we evaluate the SCEQ instrument in a unique body of students, and report that a similar factor structure is present when compared to the instrument's initial evaluation. Furthermore, we suggest that this finding lends support to the use of the SCEQ in quantifying student engagement with an introductory course in anatomy and physiology, and potentially be used to measure the impact of novel pedagogies on student engagement. 


\section{References}

Allers, N. (2010). Teaching physiology to dental students: matching teaching and learning styles in a South African dental school. Journal of Dental Education, 74, 986-992.

http://www.jdentaled.org/content/74/9/986.full.pdf+html

Armbruster, P., Patel, M., Johnson, E., \& Weiss, M. (2009). Active learning and student-centered pedagogy improve students attitudes and performance in introductory biology. CBE Life Sciences Education, 8, 203-213. http://www.lifescied.org/content/8/3/203.full.pdf+html

Brown, P.J. (2010). Process-oriented guided-inquiry learning in an introductory anatomy and physiology course with a diverse student population. Advances in Physiology Education, 34, 150155. http://advan.physiology.org/content/ajpadvan/34/3/150.full.pdf

Eagleton, S., \& Muller, A. (2011). Development of a model for whole brain learning of physiology. Advances in Physiology Education, 35, 421-426.

http://advan.physiology.org/content/ajpadvan/35/4/421.full.pdf

Eberlein, T., Kampmeier, J., Minderhout, V., Moog, R.S., Platt, T., Varma-Nelson, P., White, H.B. (2008). Pedagogies of engagement in science: a comparison of PBL, POGIL, and PLTL.

Biochemistry and Molecular Biology Education, 36, 262-273.

http://onlinelibrary.wiley.com/doi/10.1002/bmb.20204/epdf

Ernst, H., \& Colthorpe, K. (2007). The efficacy of interactive lecturing for students with diverse science backgrounds. Advances in Physiology Education, 31, 41-44.

http://advan.physiology.org/content/ajpadvan/31/1/41.full.pdf

Matheson, C. (2008). The educational value and effectiveness of lectures. Clinical Teacher, 5, 218221. http://onlinelibrary.wiley.com/doi/10.1111/j.1743-498X.2008.00238.x/epdf

Handelsman, M.M., Briggs, W.L., Sullivan, N., \& Towler, A. (2005). A measure of college student course engagement. The Journal of Educational Research, 98, 184-191.

Henige, K. (2012). Use of concept mapping in an undergraduate introductory exercise physiology course. Advances in Physiology Education, 36, 197-206.

http://advan.physiology.org/content/ajpadvan/36/3/197.full.pdf

Herrmann, K.J. (2013). The impact of cooperative learning on student engagement: Results from an intervention. Active Learning in Higher Education, 14, 175-187.

http://alh.sagepub.com/content/14/3/175.full.pdf+html

Higgins-Opitz, S.B., \&Tufts, M. (2010). Student perceptions of the use of presentations as a method of learning endocrine and gastrointestinal pathophysiology. Advances in Physiology Education, 34, 75-85. http://advan.physiology.org/content/ajpadvan/34/2/75.full.pdf

Higgins-Opitz, S.B., \& Tufts M. (2014). Performance of first-year health sciences students in a large, diverse, multidisciplinary, first-semester, physiology service module. Advances in Physiology Education, 38, 161-169. http://advan.physiology.org/content/ajpadvan/38/2/161.full.pdf

Huang, A.H., \& Carroll, R.G. (1997). Incorporating active learning into a traditional curriculum. 
Advances in Physiology Education, 18(1), S14-S23.

Kuh, G.D., Cruce, T.M., \& Shoup, R. (2008). Unmasking the Effects of Student Engagement on First-Year College Grades and Persistence. The Journal of Higher Education, 79, 540-563. https://muse.jhu.edu/journals/journal_of_higher_education/v079/79.5.kuh.pdf

Levett-Jones, T., Andersen, P., Reid-Searl, K., Guinea, S., McAllister, M., Lapkin, S., Palmer, L., \& Niddrie, M. (2015). Tag team simulation: An innovative approach for promoting active engagement of participants and observers during group simulations, Nurse Education in Practice, http://dx.doi.org/10.1016/j.nepr.2015.03.014

Michael, J., \& McFarland, J. (2011). The core principles ("big ideas”) of physiology: results of faculty surveys. Advances in Physiology Education, 35, 336-341.

http://advan.physiology.org/content/ajpadvan/35/4/336.full.pdf

Michael, J., McFarland, J., \& Wright, A. (2008). The second Conceptual Assessment in the Biological Sciences Workshop. Advances in Physiology Education, 32, 248-251.

http://advan.physiology.org/content/ajpadvan/32/3/248.full.pdf

Michael, J., Modell, H., McFarland, J., \& Cliff, W. (2009). The “core principles” of physiology: what should students understand? Advances in Physiology Education, 33, 10-16. http://advan.physiology.org/content/ajpadvan/33/1/10.full.pdf

Miller, C.J., McNear, J., \& Metz, M.J. (2013). A comparison of traditional and engaging lecture methods in a large, professional-level course. Advances in Physiology Education, 37, 347-355. http://advan.physiology.org/content/ajpadvan/37/4/347.full.pdf

Miller, C.J., \& Metz, M.J. (2014). A comparison of professional-level faculty and student perceptions of active learning: its current use, effectiveness, and barriers. Advances in Physiology Education, 38, 246-252. http://advan.physiology.org/content/ajpadvan/38/3/246.full.pdf

Modell, H.I. (2000). How to help students understand physiology? Emphasize general models. Advances in Physiology Education, 23, 101-107. http://wiki.biologyscholars.org/@api/deki/files/91/=General_Models.pdf

Rathner, J.A., Hughes, D.L., \& Schuijers, J.A. (2013). Redesigning A Core First Year Physiology Subject In Allied Health To Achieve Better Learning Outcomes. International Journal of Innovation in Science and Mathematics Education, 21, 37-52. http://openjournals.library.usyd.edu.au/index.php/CAL/article/view/7199/7668

Shaban, S., \& McLean, M. (2011). Predicting performance at medical school: can we identify atrisk students? Advances in Medical Education and Practice, 2, 139-148.

http://www.ncbi.nlm.nih.gov/pmc/articles/PMC3661252/pdf/amep-2-139.pdf

Vanags, T., Pammer, K., Brinker, J. (2013). Process-oriented guided-inquiry learning improves long-term retention of information. Advances in Physiology Education, 37, 233-241.

http://advan.physiology.org/content/ajpadvan/37/3/233.full.pdf

Wilke, R.R. (2003). The effect of active learning on student characteristics in a human physiology course for non-majors. Advances in Physiology Education, 27, 207-223. 
Brown, White, Bowmar, and Power

http://advan.physiology.org/content/ajpadvan/27/4/207.full.pdf

Zhao, C., \& Kuh, G.D. (2004). Adding Value: Learning Communities and Student Engagement. Research in Higher Education, 45, 115-138.

http://link.springer.com/article/10.1023\%2FB\%3ARIHE.0000015692.88534.de\#/page-1

Journal of the Scholarship of Teaching and Learning, Vol. 17, No. 1, February 2017. josotl.indiana.edu 